\title{
Economic Transformation, Monetary Policy and Enterprise R\&D Investment
}

\author{
Yan Zhao \\ School of Accounting \\ Fujian Jiangxia University \\ Fuzhou, China 350108
}

\begin{abstract}
The impact of macroeconomic environment and its regulatory policies on micro-enterprise investment and financing behavior has become one of the research hotspots in the company's financial field. This study takes 1754 listed companies listed on the Shanghai and Shenzhen Stock Exchanges in 2007-2017 as a sample to explore the mechanism of economic transformation, monetary policy and corporate R\&D investment. This research found the following. Economic transformation has a significant positive impact on corporate R\&D investment. Monetary policy has a positive effect on corporate R\&D investment. Monetary policy has a positive adjustment effect between economic transformation and corporate $R \& D$ investment.
\end{abstract}

Keywords-economic transformation; monetary policy; $R \& D$ investment

\section{INTRODUCTION}

Economic transformation is the only way for China's economy to become stronger and stronger. Economic transformation has become China's current major task. To drive economic transformation, we must vigorously promote technological innovation. Science and technology innovation is a powerful engine for transformation and upgrading. In the process of economic transformation, monetary policy, as an important financial tool for the government's macroeconomic regulation and control, has a unique advantage in promoting economic transformation and can play an important role. As an important variable of macroeconomic policy, monetary policy not only affects the investment opportunities of enterprises by changing the expectations of macroeconomic prospects, but also directly changes the financing environment in which enterprises are located. Enterprise R\&D investment is one of the important ways of technological innovation. Long-term, high-input, highadjustment $R \& D$ investment is more sensitive to monetary policy, and corporate $R \& D$ investment is closely linked to the external financing environment. Based on this, the discussion on the impact of economic transformation and monetary policy on corporate R\&D investment will not only help to enrich the research literature on the impact of economic transformation on $\mathrm{R} \& \mathrm{D}$ investment behavior, but also help to fully understand the impact of monetary policy on $R \& D$ investment in economic transformation. The mechanism provides evidence support for a better understanding of the relationship between China's economic transformation, monetary policy and corporate R\&D investment.

\section{LITERATURE REVIEW}

Since Keynes proposed the analytical framework of monetary policy affecting corporate investment, different scholars have expanded the research on the impact of macroeconomic environment and monetary policy on R\&D investment from different perspectives.

In foreign countries, scholars have discussed from many angles, and quantitative easing measures of macro-monetary policy can promote investment through credit supply (Bernanke \& Blinder, 1992), Monetary policy has an impact on corporate investment (Oliner \& Rudebusch,1996), interest rate has a significant impact on corporate investment (Mojon, Smets, Vermeulen, 2002), interest rates lead to a decline in corporate investment activities (Atella, Atzeni, Belvisi, 2003), corporate innovation is the key driver of economic growth, without credit constraints Under the conditions, the proportion of R\&D investment in investment has countercyclical characteristics (Aghion \& Howit, 2007), and the supportive role of banks on $\mathrm{R} \& \mathrm{D}$ is continuously strengthened (Hall \& Reenan, 2000). Exchange rate fluctuations have obvious short-term effects on domestic enterprise investment (Bahmani-Oskooee\&Hajilee,2013). The creation of new equipment, new tools, and the improvement of old equipment and old tools are technological innovation processes (Vania \& Dolores, 2014). Better policies and more new technologies can increase the size and configuration of capital. Sufficient liquidity tightening policy does not inhibit loan growth (Nguyen, Boateng, Newton, 2015). Without the combination of structural reforms, unconventional monetary policy may damage central bank credibility and policy reliability (Borio, 2016).

On the domestic front, scholars have combined the Chinese national conditions with Chinese characteristics, and this issue has also been explored in many aspects. Under the credit tightening policy, corporate $R \& D$ expenditures have dropped more or even interrupted $R \& D$ investment. The economic transformation requires the economic development mode to shift from "factor-driven" to "innovation-driven" to improve labor productivity through technological advancement, R\&D investment belt. In the economic 
transformation, monetary policy promotes its innovative investment by reducing the financing constraints of private enterprises. The impact of exchange rate appreciation on multinational R\&D investment, credit rationing significantly weakened the R\&D investment intensity of enterprises, and the tightening monetary policy can indirectly affect microenterprise R\&D investment behavior through accounting conservatism(Liu Shengqiang, Chang Wubin,2016), private listed companies And small-scale companies have suffered from higher debt financing costs and reduced the scale of technological innovation investment, the interaction of technological progress and economic structural transformation, emphasis on innovation is the regular enlightenment of history to give future economic transformation challenges, overall, technological innovation has a positive effect on economic transformation, monetary policy shock significantly affects corporate R\&D investment (Xie Qiaoqi, 2017).

In summary, the academic circles at home and abroad have carried out a lot of in-depth research work on economic transformation and monetary policy, economic transformation and enterprise R\&D investment, monetary policy and enterprise R\&D investment, and have obtained many research results, but due to sample data. There are differences in the selection of variables, model setting, and estimation methods, which lead to large differences in research conclusions and cannot provide consistent conclusions. Moreover, few literatures have incorporated economic transformation, monetary policy and corporate R\&D investment into the research framework, and analyzed their linkage mechanism and its effects. In view of this, this paper intends to incorporate economic transformation, monetary policy and enterprise $R \& D$ investment into the research framework, analyze the mechanism of action among the three, and further examine the impact of economic transformation and monetary policy on corporate $R \& D$ investment.

\section{THEORETICAL ANALYSIS AND RESEARCH HYPOTHESIS}

From an international perspective, the speed of technological innovation has accelerated markedly, and the industrial transformation based on new technological breakthroughs has shown an accelerated trend; from the domestic perspective, entering the new normal, the development momentum has shifted from relying mainly on resources and low-cost labor to innovation-driven, technology Innovation is a powerful engine for transformation and upgrading, and technological innovation is the key to improving economic quality and competitiveness. Strong scientific and technological innovation capability, excellent structure, coupled with economic development, economic structure is more reasonable, and it has stronger crisis resilience and competitiveness. Sci-tech innovation is the lever to instigate the optimization and upgrading of industrial structure, and technological innovation promotes traditional industries. The transformation and upgrading will make it develop in the direction of informationization, low carbonization and energy conservation. With the rapid development of technological innovation and the acceleration of global integration, technological advantages have become a key factor in the success of enterprises, while advanced technology and steady growth in technological progress are mainly due to the R\&D investment of local enterprises and governments with technological innovation. . During the period of economic transformation, technological innovation is an important means for enterprises to transform and upgrade, enhance their core competitiveness, and promote the growth of corporate value. $\mathrm{R} \& \mathrm{D}$ investment is an important way for enterprise science and technology innovation. R\&D investment activities are the engine of enterprise science and technology innovation, and R\&D investment is a measure of enterprises. One of the important indicators of the potential of scientific and technological innovation. Based on the above analysis, this paper proposes the following assumptions.

Hypothesis 1: Corporate R\&D investment is positively related to economic transformation.

Economic transformation is a major task for China. Economic transformation is a complex and unbalanced dynamic process. A series of macroeconomic policies including monetary policy are needed in the process of economic transformation. Monetary policy is closely related to every industry and enterprise in economic transformation. Money supply and interest rate are important tools for monetary policy to influence economic transformation. Economic transformation and monetary policy transformation have synergistic relationship. The adjustment of monetary policy to the economy is partly achieved by influencing public expectations. Especially when the economic balance is adjusted, the monetary policy has uncertainties and high variability in the direction of regulation. Sex and volatility often affect business expectations.

The investment in $R \& D$ of enterprises is affected by the expectation of enterprises. In the initial stage of R\&D investment, when financing is difficult or the technical risk is very high, the company may choose to withdraw from R\&D. The enterprise is equivalent to obtaining an exit option; when financing is difficult or the technical risk is low, The enterprise may choose to continue to invest in research and development. The enterprise is equivalent to obtaining a call option; the enterprise R\&D investment has a call option and an exit option, and all options in the $R \& D$ stage may constitute a compound option. When the uncertainty of monetary policy is low, enterprises can form relatively stable expectations and make $\mathrm{R} \& \mathrm{D}$ investment decisions accordingly. When monetary policy is tightened, enterprises reduce the scale of $R \& D$ investment, and expand the $R \& D$ investment scale when monetary policy is loose. When monetary policy has higher uncertainty, enterprises cannot form stable expectations for the future. When faced with loose monetary policy, they are worried that monetary policy may be tightened in the future and cannot expand the scale of R\&D investment rapidly, which weakens the investment of R\&D in loose monetary policy. The promotion effect; when faced with tight monetary policy, it is worried that the future 
monetary policy will be loose and maintain the current level of R\&D investment. This expectation has somewhat inhibited the negative impact of monetary policy tightening on corporate $\mathrm{R} \& \mathrm{D}$ investment. The transmission mechanism of monetary policy to enterprises is mainly realized through interest rate changes and credit rationing. Interest rate changes and credit rationing jointly determine the financing environment of enterprises. Monetary policy promotes innovation investment by reducing corporate financing constraints. Since enterprise R\&D is a complex system engineering, enterprise R\&D needs a large amount of capital for long-term continuous investment. Insufficient funds often lead to the termination or failure of R\&D. The adequacy of funds is the key to R\&D activities. The funds for enterprise R\&D investment mainly come from internal financing, equity financing and debt financing. Since R\&D investment is a long-term investment, it needs continuous investment of enterprises, and internal financing is easily affected by the volatility of corporate profits. It is difficult for enterprises to rely on internal financing. Enterprises implement long-term, high-input, high-risk R\&D investment, and adopting equity financing has certain conditions. Many enterprises do not have the conditions for equity financing. Therefore, obtaining external financing support is one of the important sources of funds for R\&D investment. . External financing is also vulnerable to monetary policy. When monetary policy tightens, the decrease in money supply leads to a decrease in bank liquidity, which increases the difficulty of $R \& D$ project financing and external financing costs, and the reduction of guarantee capacity due to the tightening of market liquidity further increases the degree of financing constraints. In addition, banks are more inclined to issue low-risk and shortterm loan projects when monetary policy contracts, and banks' lending practices conflict with the long-term nature of corporate R\&D investment. After the tightening of monetary policy led to a decrease in the money supply, the real interest rate of the market was raised, and the cost of capital increased, resulting in a negative return on the net present value of the corresponding $\mathrm{R} \& \mathrm{D}$ projects, which reduced investment opportunities and inhibited $R \& D$ investment behavior. Based on the above theoretical analysis, this paper proposes the following assumptions.

Hypothesis 2: Monetary policy is positively related to corporate $\mathrm{R} \& \mathrm{D}$ investment.

Hypothesis 3: Both economic transformation and monetary policy have a positive effect on corporate R\&D investment. Monetary policy has a positive adjustment effect between economic transformation and corporate R\&D investment.

\section{RESEARCH DESIGN}

\section{A. Sample Selection and Data Source}

This paper selects the Shanghai-Shenzhen A-share listed companies from 2007 to 2017 as the initial sample, and treats the initial samples as follows: (1) Excluding financial companies; (2) Excluding companies with missing R\&D data; (3) Eliminating missing data And companies with extremely abnormal data. Finally, 1754 companies were sampled. The monetary policy variable data comes from the website of the People's Bank of China and the China Financial Statistics Yearbook, and is hand-finished. R\&D expenses come from the Wind database and the CSMAR database, and other financial data comes from the CSMAR database. The economic transformation data is derived from the China Statistical Yearbook and the official website of the China Statistics Bureau. In order to study the robustness of the results, this paper performs winsorize processing on the $1 \%$ and $99 \%$ quantiles for continuous variables. Data processing uses Stata 14.0 and Execl 2016.

\section{B. Variable Definitions and Metrics}

R\&D investment definition and measurement: From the existing literature on the research and development investment based on the micro level, most studies usually use the ratio of $R \& D$ investment and sales income to measure the $R \& D$ investment level, which is a relative indicator. Some documents also use absolute indicators of $R \& D$ investment to reflect $R \& D$ investment levels. Like most documents, this paper uses $R \& D$ investment intensity (R\&D investment/operating income) as a measure of R\&D investment. $R \& D$ investment is represented by $R D$.

Monetary policy definition and measurement: With regard to the proxy variable of monetary policy, Bernanke and Blinder use the change of federal funds rate to better reflect the change of monetary policy. Cover and other believe that M2 growth can better measure monetary policy, Romer adopts The Federal Open Market Committee's meeting record design dummy variables measure tight monetary policy. Domestic scholars have more to use the money supply and credit growth as a measure of monetary policy. Drawing on existing research at home and abroad, considering the actual situation in China, this paper measures the monetary policy by using the growth rate of money supply. Monetary policy is represented by MP.

Definition and measurement of economic transformation. Economic transformation is a change in the original economic development mode, economic structure and even the economic development mechanism of a country or region in order to cope with the bottlenecks and problems in its own economic development. An economic operating state turns to another state. At present, the economic transformation measurement methods mainly include measuring the economic transformation with the proportion of the tertiary industry as the core index, measuring the economic transformation with the degree of development of emerging industries, and measuring the economic transformation with total factor productivity and its decomposition. Drawing on the domestic and international economic transformation measurement methods, this paper uses the GDP ratio of the tertiary industry as an indicator to measure the level of economic transformation. Economic transformation is represented by ET.

Control variable definitions and metrics. This paper uses business income growth rate to measure corporate growth, Growth is represented by Growth. This paper measures the cash flow by using the ratio of net cash flow from operating 
activities to total assets at the end of the period, the cash flow is represented by Cash. This paper measures the profitability by using the weighted return on equity, Profitability is represented by ROE. The gearing ratio is measured as the ratio of the total liabilities at the end of the period to the total assets at the end of the period, Assets and liabilities is represented by Lev. This paper uses the natural logarithm of total assets at the end of the year to measure the size of the enterprise, Business scale is represented by Size. This article measures the age of the company from the year the company was established to the end of the previous year, Business age is represented by Age. In addition, this article sets the annual and industry as dummy variables to control annual and industry impact.

\section{Research Model Design}

Based on the relevant experience of the existing literature, this paper will examine the basic econometric regression model of the impact of economic transformation on R\&D investment as follows.

$$
\begin{aligned}
& \text { RD }_{i, t}=\alpha_{0}+\alpha_{1} \text { ET }_{t}+\alpha_{2} \text { Cash }_{i, t-1}+ \\
& \alpha_{3} \text { Growth }_{i, t-1}+\alpha_{4} \text { ROE }_{i, t-1}+\alpha_{5} \text { Lev }_{i, t-1} \\
& +\alpha_{6} \text { Size }_{i, t-1}+\alpha_{7} \text { Age }_{i, t-1}+\varepsilon_{i, t-1}
\end{aligned}
$$

Based on the relevant experience of the existing literature, this paper will examine the basic econometric regression model of the impact of monetary policy on R\&D investment as follows.

$$
\begin{aligned}
& R D_{i, t}=\mu_{0}+\mu_{1} M_{t}+\mu_{2} \operatorname{Cash}_{i, t-1}+ \\
& \mu_{3} \text { Growth }_{i, t-1}+\mu_{4} \text { ROE }_{i, t-1}+\mu_{5} \text { Lev }_{i, t-1} \text { Model (2) } \\
& +\mu_{6} \text { Size }_{i, t-1}+\mu_{7} \text { Age }_{i, t-1}+\varepsilon
\end{aligned}
$$

Based on the relevant experience of the existing literature, this paper will examine the basic econometric regression model of economic transformation and monetary policy on the impact of $R \& D$ investment and the monetary policy adjustment effect as follows.

$$
\begin{aligned}
& R D_{i, t}=\eta_{0}+\eta_{1} \text { MP }_{t}+\eta_{2} E T_{t}+\eta_{3} E T_{t} \times M P_{t}+ \\
& \eta_{4} \text { Cash }_{i, t-1}+\eta_{5} \text { Growth }_{i, t-1}+\eta_{6} \text { ROE }_{i, t-1} \\
& +\eta_{7} \text { Lev }_{i, t-1}+\eta_{8} \text { Size }_{i, t-1}+\eta_{9} \text { Age }_{i, t-1}+\varepsilon
\end{aligned}
$$

\section{EMPIRICAL ANALYSIS}

\section{A. Descriptive Statistics and Analysis}

"Table I" gives descriptive statistics for the main variables. The sample company's $R \& D$ investment average is $4.12 \%$, and there is a big gap between the maximum and minimum values, indicating that there are large differences in R\&D investment. The mean value of monetary policy variables is $8.32 \%$, and there is a big difference between the maximum and minimum values, indicating that there is greater volatility in monetary policy. The mean value of the economic transformation variable is $2.41 \%$, and there is a big difference between the maximum value and the minimum value, indicating that the economic transformation varies greatly in different years. The average growth rate of the sample company is $14.37 \%$, the maximum value is $37.45 \%$, and the minimum value is negative $17.42 \%$, indicating that the sample companies have large differences in growth. The average profitability of the sample company is $7.24 \%$, and there is a big difference between the maximum value and the minimum value, indicating that the sample company has a large difference in profitability. The average cash flow of the sample company is $1.36 \%$, and there is a big difference between the maximum value and the minimum value, indicating that the sample company's operating activities have a large difference in cash flow from operating activities. The average asset-liability ratio of the sample company is $42.51 \%$, and there is a big difference between the maximum and minimum values, indicating that the sample companies have large differences in debt levels.

TABLE I. DESCRIPTIVE STATISTICS OF MAIN VARIABLES

\begin{tabular}{|c|l|l|l|l|}
\hline Variable & Mean & \multicolumn{1}{|c|}{ Median } & Maximum & \multicolumn{1}{|c|}{ Minimum } \\
\hline $\boldsymbol{R D}$ & 0.0412 & 0.0168 & 0.7524 & 0.0001 \\
\hline $\boldsymbol{M P}$ & 0.0832 & 0.0642 & 0.1945 & -0.0102 \\
\hline ET & 0.0241 & 0.0108 & 0.5140 & 0.0324 \\
\hline Growth & 0.1437 & 0.1173 & 0.3745 & -0.1742 \\
\hline ROE & 0.0724 & 0.0614 & 0.3162 & -0.2419 \\
\hline Cash & 0.0136 & 0.0104 & 0.1521 & -0.0023 \\
\hline Lev & 0.4251 & 0.3972 & 0.8324 & 0.0731 \\
\hline Size & 21.613 & 21.132 & 24.753 & 12.462 \\
\hline
\end{tabular}

\section{B. Empirical Results and Analysis}

Using panel data, using the fixed effect model, the hypothetical test results are shown in "Table II". The column (1) in "Table II" is the estimation result of equation (1), which shows the effect of economic transformation on the R\&D investment of enterprises. The column (2) in Table II is the estimation result of equation (2), which shows the effect of monetary policy on the R\&D investment of enterprises. The column (3) in Table II is the estimation result of equation (3), which shows the effect of economic transformation and monetary policy on enterprise $R \& D$ investment, and the adjustment effect of monetary policy on economic transformation and enterprise $R \& D$ investment.

From the regression results in column (1) of Table II, the coefficient of economic transformation is 0.021 , which is significantly positive and significant at $5 \%$, indicating that economic transformation has a significant positive impact on corporate R\&D investment, which fully demonstrates that Under the background of economic transformation and driving enterprise innovation and development, enterprise R\&D investment is an important way to cater to economic transformation. From the regression results of control variables, the estimation coefficients of growth, profitability and cash flow are significantly positive, indicating that the growth, profitability and cash flow of enterprises during the economic transition have a positive effect on $R \& D$ investment, which indicates the enterprise itself. Profitability is an important factor in stimulating enterprises to expand the scale of R\&D investment; the estimation coefficient of assetliability ratio is significantly negative, indicating that the existing asset-liability ratio of enterprises has a restraining effect on R\&D investment of enterprises, and the existing 
debt ratio of enterprises will reduce future liabilities. Level, the reduction of future debt levels may reduce the scale of R\&D investment; the estimated coefficient of enterprise age and scale is significantly negative, which means that the longer the company is established, the more the company will increase R\&D investment, which indicates that the company is not supporting the company to expand R\&D. Factors affecting the size of the investment. Hypothesis 1 is verified.

From the regression results in column (2) of "Table II", the estimated coefficient of monetary policy is 0.031 , which is significantly positive and significant at $5 \%$, indicating that monetary policy has a significant positive impact on corporate R\&D investment. From the regression results of control variables, the estimation coefficients of growth, profitability and cash flow are significantly positive, indicating that the growth, profitability and cash flow of enterprises under the influence of monetary policy have an incentive effect on R\&D investment; The estimated coefficient is significantly negative, indicating that under the influence of monetary policy, the scale of the existing liabilities of enterprises has restricted the expansion of the scale of $R \& D$ investment in the future; the estimated coefficient of the age and scale of the enterprise is significantly negative, indicating that the age and scale of the enterprise are not to promote the $\mathrm{R} \& \mathrm{D}$ of enterprises. Influencing factors of investment. Hypothesis 2 is verified.

From the results of (3) regression in "Table II", the estimated coefficient of economic transformation is 0.019 , which is significantly positive and significant at $5 \%$; the estimated coefficient of monetary policy is 0.028 , which is significantly positive and significant at $5 \%$.The estimated coefficient of economic transformation and monetary policy intersection is 0.017, which is significantly positive and significant at $5 \%$.It can be seen that monetary policy has a regulating effect on the positive correlation between economic transformation and corporate R\&D investment, and monetary policy has a positive adjustment effect on economic transformation and enterprise $R \& D$ investment. From the regression results of the control variables, the estimation coefficient of growth, profitability and cash flow of the enterprise is positive and significant, indicating that during the period of economic transition, the monetary policy affects the $R \& D$ investment of the enterprise, the growth, profitability and cash flow of the enterprise. It has a promoting effect on enterprise R\&D investment; the estimation coefficient of corporate asset-liability ratio is negative and significant, indicating that the existing debt ratio of enterprises will increase the future debt conditions and loan costs of enterprises, and the existing debt level of enterprises will weaken the $R \& D$ investment level of enterprises. Hypothesis 3 is verified.
TABLE II. EMPIRICAL RESULTS OF ECONOMIC TRANSFORMATION, MONETARY POLICY AND ENTERPRISE R\&D INVESTMENT

\begin{tabular}{|c|l|l|l|}
\hline Variable & \multicolumn{1}{|c|}{ Model (1) } & \multicolumn{1}{|c|}{ Model(2) } & \multicolumn{1}{|c|}{ Model(3) } \\
\hline ET & $0.021^{* *}$ & & $0.019^{* *}$ \\
& $(3.835)$ & & $(3.915)$ \\
\hline MP & & $0.031^{* *}$ & $0.028^{* *}$ \\
& & $(4.135)$ & $(3.967)$ \\
\hline MP×ET & & & $0.017^{* *}$ \\
& & & $(2.875)$ \\
\hline Growth & $0.029^{* * *}$ & $0.035^{* * *}$ & $0.031^{* * *}$ \\
& $(4.124)$ & $(3.764)$ & $(4.368)$ \\
\hline ROE & $0.011^{* * *}$ & $0.009^{* * *}$ & $0.008^{* * *}$ \\
& $(4.124)$ & $(3.975)$ & $(3.768)$ \\
\hline Lev & $-0.013^{* *}$ & $-0.009^{* *}$ & $-0.015^{* *}$ \\
& $(-3.246)$ & $(-3.572)$ & $(-3.846)$ \\
\hline Cash & $0.003^{* *}$ & $0.006^{* *}$ & $0.005^{* *}$ \\
& $(3.461)$ & $(3.712)$ & $(3.146)$ \\
\hline Age & $-0.001^{* *}$ & $-0.001^{* *}$ & $-0.001^{* *}$ \\
& $(-3.164)$ & $(-3.325)$ & $(-3.706)$ \\
\hline Size & $-0.0001^{* *}$ & $-0.0009^{* *}$ & $-0.0004^{* *}$ \\
& $(-2.661)$ & $(-2.912)$ & $(-2.762)$ \\
\hline constant & $0.024^{* *}$ & $0.037^{* *}$ & $0.043^{* *}$ \\
& $(4.674)$ & $(5.142)$ & $(4.362)$ \\
\hline year & controlled & controlled & controlled \\
\hline industry & controlled & controlled & controlled \\
\hline Adj- $R^{2}$ & 0.362 & 0.317 & 0.358 \\
\hline DW value & 2.04 & 2.14 & 2.18 \\
\hline Sample size & 1754 & 1754 & 1754 \\
\hline
\end{tabular}

a. Note: $* * *, * *$, and $*$ indicate that the coefficient passes the significant level of $1 \%, 5 \%$, and $10 \%$, respectively, and the t-statistic after correcting the heteroscedasticity in parentheses.

\section{Robustness Test}

In order to investigate the reliability of the above empirical test results, this paper conducts the following aspects of robustness test: First, change the definition of economic transformation, use unit GDP energy consumption as a measure of economic transformation; second, change the definition of monetary policy The method uses credit growth rate to measure monetary policy; the third is to change the extreme value of the processing method, $1 \%$ and $99 \%$ winsorize processing to $5 \%$ and $95 \%$ winsorize processing, etc., re-evaluation test, robustness test results see "Table III". The results of the robustness estimation are not substantially different from the results reported above. 
TABLE III. RESUlTS OF ECONOMIC TRANSFORMATION, MONETARY POLICY AND FIRM R\&D INVESTMENT ROBUSTNESS TEST

\begin{tabular}{|c|c|c|c|}
\hline Variable & Model(1) & Model(2) & Model(3) \\
\hline$E T$ & $\begin{array}{l}0.018 * * \\
(3.617)\end{array}$ & & $\begin{array}{l}0.017 * * \\
(3.582)\end{array}$ \\
\hline$M P$ & & $\begin{array}{l}0.026^{* * *} \\
(3.835)\end{array}$ & $\begin{array}{l}0.018 * * \\
(3.371)\end{array}$ \\
\hline$M P \times E T$ & & & $\begin{array}{l}0.019 * * \\
(2.912) \\
\end{array}$ \\
\hline Growth & $\begin{array}{l}0.019 * * * \\
(3.234)\end{array}$ & $\begin{array}{l}0.027 * * * \\
(3.148)\end{array}$ & $\begin{array}{l}0.028 * * * \\
(3.814)\end{array}$ \\
\hline$R O E$ & $\begin{array}{l}0.009 * * * \\
(3.478)\end{array}$ & $\begin{array}{l}0.014 * * * \\
(3.351)\end{array}$ & $\begin{array}{l}0.007 * * * \\
(3.581)\end{array}$ \\
\hline Lev & $\begin{array}{l}-0.003 * * \\
(-3.651)\end{array}$ & $\begin{array}{l}-0.010^{* *} * \\
(-3.126)\end{array}$ & $\begin{array}{l}-0.012 * * \\
(-3.279)\end{array}$ \\
\hline Cash & $\begin{array}{l}0.001 * * \\
(3.641)\end{array}$ & $\begin{array}{l}0.003 * * \\
(3.527)\end{array}$ & $\begin{array}{l}0.004 * * \\
(3.561)\end{array}$ \\
\hline Age & $\begin{array}{l}-0.0009 * * \\
(-3.614) \\
\end{array}$ & $\begin{array}{l}-0.0007 * * \\
(-3.288)\end{array}$ & $\begin{array}{l}-0.0003 * * \\
(-3.068)\end{array}$ \\
\hline Size & $\begin{array}{l}-0.0007 * * \\
(-3.161)\end{array}$ & $\begin{array}{l}-0.0006 * * \\
(-3.172)\end{array}$ & $\begin{array}{l}-0.0004 * * \\
(-2.921)\end{array}$ \\
\hline constant & $\begin{array}{l}0.017 * * \\
(3.674)\end{array}$ & $\begin{array}{l}0.024 * * \\
(4.412)\end{array}$ & $\begin{array}{l}0.013 * * \\
(3.692)\end{array}$ \\
\hline year & controlled & controlled & controlled \\
\hline industry & controlled & controlled & controlled \\
\hline$A d j-R^{2}$ & 0.341 & 0.308 & 0.327 \\
\hline DW value & 2.13 & 2.35 & 2.06 \\
\hline Sample size & 1754 & 1754 & 1754 \\
\hline
\end{tabular}

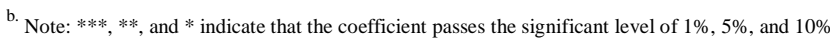
respectively, and the t-statistic after correcting the heteroscedasticity in parentheses.

\section{CONCLUSION}

Based on the relationship between economic transformation, monetary policy and enterprise R\&D investment, this study proposes a new research idea of "economic transformation $\rightarrow$ monetary policy $\rightarrow$ financing environment $\rightarrow$ R\&D investment $\rightarrow$ technological innovation $\rightarrow$ economic transformation", and analyzes the mechanism of economic transformation affecting monetary policy. Analyze the mechanism of economic transformation affecting R\&D investment, and explain the adjustment mechanism of monetary policy between economic transformation and R\&D investment. This study uses the sample data of 2007-2017 of A-share listed companies on the Shanghai and Shenzhen Stock Exchanges to empirically test the linkage effect between economic transformation, monetary policy and corporate R\&D investment. The study finds that economic transformation has an incentive effect on R\&D investment of enterprises. Monetary policy has a positive impact on corporate R\&D investment. Monetary policy has a positive adjustment effect between economic transformation and corporate R\&D investment. The conclusions of this study can profoundly reveal the intrinsic mechanism of economic transformation, monetary policy and enterprise R\&D investment, and provide decisionmaking reference for relevant decision makers.

The conclusions of this paper have policy implications for enterprise R\&D investment decision-making and China's monetary policy regulation: enterprise $R \& D$ investment decision should consider the financing environment change and financing constraints brought by monetary policy, comprehensively coordinate R\&D funding sources to ensure the smooth implementation of R\&D; To enhance forward- looking and transparency, monetary policy should actively guide enterprises' expectations, and relevant structural monetary policies should be formulated for corporate R\&D investment.

\section{REFERENCES}

[1] Bernanke,B.,and BlinderA.S.The Federal Funds Rate and the Transmission of Monetary Policy[J].American Economic Review, 1992(4): 901-921.

[2] Oliner S D., R udebusch G D.Is There a broad credit channel for monetary policy?[J].Economic R eview, 1996(1):3-13.

[3] Mojon B, Smets F, Vermeulen P.Investment and monetary policy in the Euro Area[J].Journal of Banking and Finance, 2002(11):21112129.

[4] Atella,V.,Atzeni,G.and Belvisi,P..Investment and exchange rate uncertainty[J].Journal of Policy Medeling,2003(8):811-824.

[5] Aghion,P.and Howitt,P.Appropriate growth policy[J].Journal of the European Economic Association,2007(4):268-269.

[6] Hall,B.H.and Van Reenan,J.How Effective Are Fiscal Incentives for R\&D? A Review of the Evidence[J]. Research Policy,2000(29):449469.

[7] Bahmani-Oskooee,M. and Hajilee,M..Exchange rate volatility and its impact on domestic investment[J].Research in Economics,2013,67(1):2-5.

[8] Vania S,Dolores A.H.Productivity,R\&D spillovers and educational attainment[J].Oxford Bulletin of Economics and Statistics ,2014(76):1-23.

[9] Nguyen.V.H.T.,Boateng,A.,Newton,D..Involuntary Excess Reserves, the Reserve Requirements and Credit Rationing in China Applied Economics,2015(14):1424-1437.

[10] Borio,C..Revisting three intellectual pillars of monetary policy[J].Cato Journal,2016(2):213-238.

[11] Liu Shengqiang, Chang Wubin.Monetary Policy, Internal Capital Markets and R\&D Investment - Cash Flow Sensitivity[J].journal of Soft Science,2016 (12): 6-9.

[12] Xie Qiaoqi.Research on the Impact of Monetary Policy Impact on Enterprise R\&D Investment[J].Journal of scientific research,2017(1):93-96. 